\title{
The relative importance of exogenous and substrate-derived nitrogen for microbial growth during leaf decomposition
}

\author{
B. M. Cheever,${ }^{1,3}$ J. R. Webster, ${ }^{1}$ E. E. Bilger,${ }^{1}$ and S. A. Thomas ${ }^{2}$ \\ ${ }^{1}$ Department of Biological Sciences, Virginia Polytechnic Institute and State University, \\ Blacksburg, Virginia 24061 USA \\ ${ }^{2}$ School of Natural Resources, University of Nebraska, Lincoln, Nebraska 68583 USA
}

\begin{abstract}
Heterotrophic microbes colonizing detritus obtain nitrogen (N) for growth by assimilating $\mathrm{N}$ from their substrate or immobilizing exogenous inorganic $\mathrm{N}$. Microbial use of these two pools has different implications for $\mathrm{N}$ cycling and organic matter decomposition in the face of the global increase in biologically available $\mathrm{N}$. We used sugar maple leaves labeled with ${ }^{15} \mathrm{~N}$ to differentiate between microbial $\mathrm{N}$ that had been assimilated from the leaf substrate (enriched with ${ }^{15} \mathrm{~N}$ ) or immobilized from the water (natural abundance ${ }^{15} \mathrm{~N}:{ }^{14} \mathrm{~N}$ ) in five Appalachian streams ranging in ambient $\mathrm{NO}_{3}-\mathrm{N}$ concentrations from about 5 to $900 \mu \mathrm{g} \mathrm{NO} \mathrm{NO}_{3}$ $\mathrm{N} / \mathrm{L}$. Ambient $\mathrm{NO}_{3}{ }^{-}$concentration increased sugar maple decomposition rate but did not influence the proportion of microbial $\mathrm{N}$ derived from substrate or exogenous pools. Instead, these proportions were strongly influenced by the percentage of detrital ash-free dry mass (AFDM) remaining. Substrate-derived $\mathrm{N}$ made up a large proportion of the microbial $\mathrm{N}$ after the first $24 \mathrm{~h}$ in all streams. Detrital and microbial isotopic ${ }^{15} \mathrm{~N}$ signatures approached that of the water as decomposition progressed in all streams, suggesting that exogenous $\mathrm{N}$ may be the predominant source of $\mathrm{N}$ for meeting microbial requirements even when exogenous $\mathrm{N}$ concentrations are low. Our results support predictions of more rapid decomposition of organic matter in response to increased $\mathrm{N}$ availability and highlight the tight coupling of processes driving microbial $\mathrm{N}$ cycling and organic matter decomposition.
\end{abstract}

Key words: ${ }^{15} \mathrm{~N}$; assimilation; chloroform fumigation; heterotrophic microbes; immobilization; nitrogen availability; nitrogen cycling; organic matter decomposition; streams.

\section{INTRODUCTION}

Human activities have increased the amount of bioavailable nitrogen $(\mathrm{N})$ in the biosphere (Vitousek et al. 1997). This increase may alter the rates of $\mathrm{N}$ cycling (Galloway et al. 2003) as well as the interactions of $\mathrm{N}$ with other elemental cycles (Finzi et al. 2011). Biosynthesis couples $\mathrm{N}$ with other elements often in specific ratios determined by an organism's growth requirements (Sterner and Elser 2002, Schlesinger et al. 2011). Several ecosystem scale processes couple $\mathrm{N}$ with carbon (C), including primary production and organic matter decomposition. Heterotrophic microbes that decompose organic matter often require $\mathrm{N}$ in excess of what is readily available in their substrate to support growth, requiring microbes to access a supplementary source of N (Parton et al. 2007).

Potential supplementary sources of $\mathrm{N}$ available to microbes include $\mathrm{N}$ bound in recalcitrant substrate compounds and exogenous dissolved inorganic and organic N (DIN and DON, respectively) from the

Manuscript received 31 July 2012; revised 11 January 2013; accepted 31 January 2012. Corresponding Editor: W. V. Sobczak.

${ }^{3}$ Present address: Department of Biology, Trent University, Peterborough, Ontario K9J 7B8 Canada.

E-mail: bethcheever@trentu.ca surrounding environment. The relative importance of substrate-derived and exogenous pools in meeting microbial $\mathrm{N}$ requirements is likely to determine how microbes respond to anthropogenic sources of biologically available $\mathrm{N}$ with implications for organic matter decomposition rates and $\mathrm{CO}_{2}$ evolution (Carreiro et al. 2000). There is support for microbial utilization of both pools in studies of terrestrial ecosystems. Measures of initial substrate quality are often correlated with microbial activity (Melillo et al. 1982, Berg et al. 2003, Parton et al. 2007), and microbes produce exoenzymes that break up recalcitrant compounds such as lignin, which can complex with N (Moorhead and Sinsabaugh 2006, Sinsabaugh and Shah 2011). However, exogenous nutrient availability can also influence microbial activity (e.g., Hunt et al. 1988, Vivanco and Austin 2011), and N content of detritus often increases during the initial stages of decomposition (Aber and Melillo 1982, McClaugherty et al. 1985, Berg and McClaugherty 1989), presumably due to microbial immobilization of exogenous DIN. Recent simulations of nutrient dynamics during organic matter decomposition assume microbial use of DIN (Webster et al. 2009, Manzoni et al. 2010), although the magnitude of this flux is likely to be dependent on initial substrate quality and DIN (Parton et al. 2007) form and availability. 


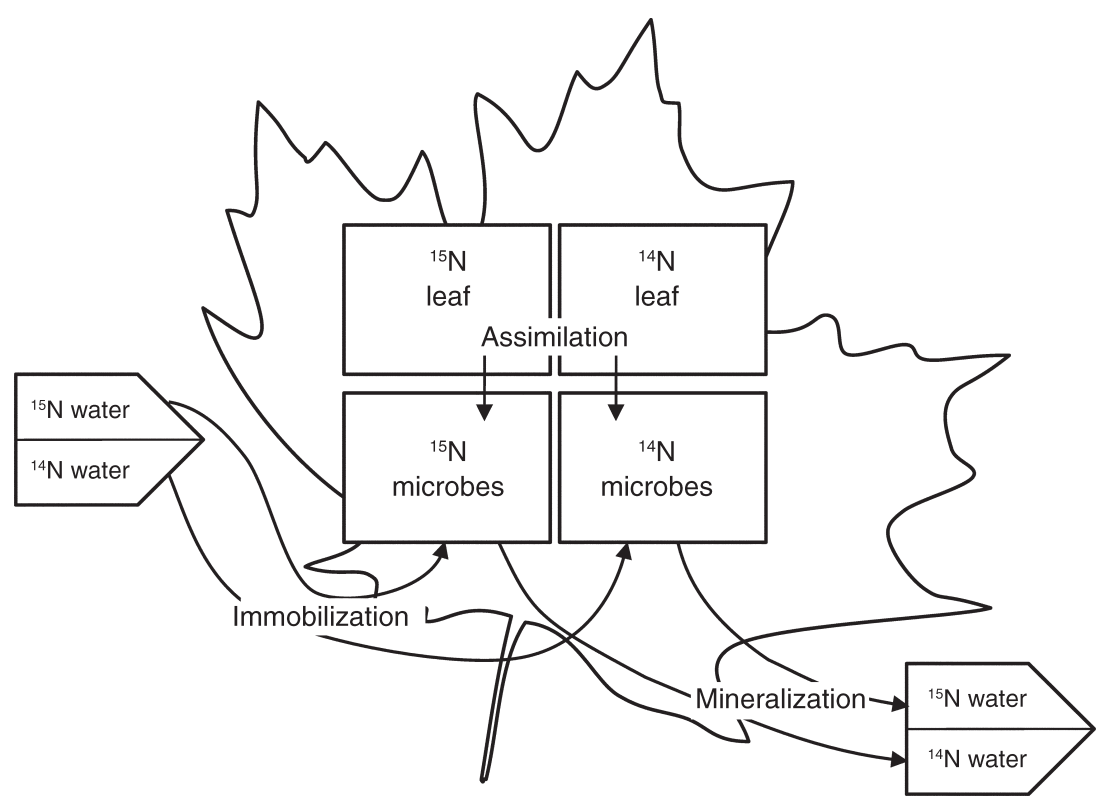

Fig. 1. Conceptual diagram tracing the movement of ${ }^{14} \mathrm{~N}$ and ${ }^{15} \mathrm{~N}$. Boxes represent $\mathrm{N}$ standing stocks (mass) and arrows represent $\mathrm{N}$ fluxes (mass per time).

We investigated the relative roles of substrate and exogenous $\mathrm{N}$ pools in meeting heterotrophic microbial $\mathrm{N}$ requirements in headwater streams. Temperate, forested, headwater streams are detrital-based ecosystems (Fisher and Likens 1973). Whereas the exogenous $\mathrm{N}$ supply available to litter-associated microbes in terrestrial ecosystems is highly dependent on precipitation and is therefore temporally variable, the dissolved exogenous nutrient pool in lotic ecosystems is constantly renewed from upstream. Microbial activity associated with leaf decomposition in lotic systems has been shown to respond to both the concentration of DIN in the water column and initial litter quality (e.g., Hynes and Kaushik 1969, Suberkropp and Chauvet 1995, Suberkropp et al. 2010). Our objective was to assess the predominant sources of $\mathrm{N}$ for stream heterotrophic microbes over the course of decomposition across a gradient of DIN availability in order to determine the patterns in microbial $\mathrm{N}$ use over the decay continuum and provide insight into how these patterns may change as global $\mathrm{N}$ availability continues to increase.

We used a natural gradient of DIN availability and leaves labeled with a stable isotope of $\mathrm{N}$ to address this objective (Fig. 1). Leaf litter collected from the streams at any given time (called detritus from here on) can conceptually be separated into two pools: leaf tissue and microbial biomass. Nitrogen enters microbial biomass from leaf tissue via assimilation or from the water via immobilization and is returned to the water from microbial biomass via mineralization. We used sugar maple leaves labeled with ${ }^{15} \mathrm{~N}$ in order to differentiate $\mathrm{N}$ in microbial biomass that had been assimilated (enriched in ${ }^{15} \mathrm{~N}$ ) or immobilized (stream water natural abundance ${ }^{15} \mathrm{~N}:{ }^{14} \mathrm{~N}$ ) in five streams spanning a gradient in ambient
DIN concentration. Using this design, we considered the following alternative temporal responses of microbial biomass from a single site: (1) if microbes relied predominantly on leaf compounds as their source of $\mathrm{N}$, microbial biomass would become progressively enriched over the course of decomposition, or (2) if microbes relied predominantly on DIN as their $\mathrm{N}$ source, the isotopic signature of the microbial biomass would reflect the isotope ratio of the water DIN pool (i.e., natural abundance) over the course of decomposition. The influence of DIN availability on microbial DIN use was also investigated using this design. If high DIN availability shifts microbial $\mathrm{N}$ use to exogenous sources, then the isotopic signature of the microbial biomass in streams with high DIN concentration would more rapidly converge on the ${ }^{15} \mathrm{~N}$ signature of the DIN pool than microbial biomass in low DIN streams.

\section{Methods \\ Study sites}

Field research was conducted in five forested headwater streams from November 2009 to February 2010. Stonecrop Creek (SC), Little Stony Creek (LS), Little Back Creek (LB), and Smith Creek (SM) are located in southern Virginia, and Hugh White Creek (HW) drains a reference watershed at Coweeta Hydrologic Laboratory in North Carolina. All five streams are similarsized, soft water streams located in the granitic geology of the southern Appalachians. They are shaded on at least one bank with deciduous riparian vegetation but differ widely in land use ranging from reference forest (HW, LS), second-growth forest (SC), partially residential (LB), to primarily agriculture (SM). Differences in 
chemistry are probably related to these differences in land use (Cheever et al. 2012). LS is at an elevation of $1182 \mathrm{~m}$ and the other streams range from 596 to $815 \mathrm{~m}$.

The five streams span a gradient of DIN and phosphorus concentration, ranging from below detection to approximately $900 \mu \mathrm{g} / \mathrm{L}$ and $7.0 \mu \mathrm{g} / \mathrm{L}$ respectively. The molar ratio of DIN (measured as $\mathrm{NH}_{4}-\mathrm{N}+$ $\mathrm{NO}_{3}-\mathrm{N}$ concentration) to soluble reactive phosphorus (SRP) also varied across these sites, ranging from approximately 2.5 to over 600 .

\section{Leaf pack deployment and collection}

Sugar maple (Acer saccharum) leaves labeled with ${ }^{15} \mathrm{~N}$ were obtained from Timothy Fahey, Department of Natural Resources, Cornell University. The labeling process was described by Fahey et al. (2011). Briefly, sugar maple saplings were fertilized with 99 atom $\%$ enriched ${ }^{15} \mathrm{NH}_{4} \mathrm{Cl}\left(0.25 \mathrm{~g}{ }^{15} \mathrm{~N} / \mathrm{m}^{2}\right)$ during the summer growing season. Abscised leaves were collected the following fall and one year later. Leaves were dried at room temperature to a constant mass. Sugar maple occurs throughout the region of this study, but it is not generally a dominant riparian species. At Stonecrop Creek, it is a major species along the stream but, at the other sites, red maple (Acer rubrum) is more common. These two species are closely related, and the decomposition dynamics of both have been well studied (e.g., Petersen and Cummins 1974, Eggert and Wallace 2003, Carter and Suberkropp 2004, Das et al. 2007, Fahey et al. 2011).

We gently crushed the dried leaves into small fragments $\left(\sim 1-2 \mathrm{~cm}^{2}\right)$ and sieved ( $2 \mathrm{~mm}$ mesh size) to remove small particles. We then mixed the fragments in order to decrease variability in ${ }^{15} \mathrm{~N}$ label distribution within the leaf packs. After sieving, 2 or $10 \mathrm{~g}$ of leaf fragments were sealed into screen packs with $2 \mathrm{~mm}$ mesh size. This mesh size excluded macroinvertebrates from the leaves, which allowed us to assess microbial processes. Twenty packs of each mass were anchored to the beds of the five study streams on 8 November 2009. Four packs of each mass were collected from each stream $24 \mathrm{~h}$ after deployment and periodically over the next 12-15 weeks. An additional set of packs was transported to and from the sites but not deployed in order to correct for mass loss due to handling and to establish initial nutrient conditions. Packs were collected by removing them from the water column and placing each pack in a plastic press-seal bag of stream water. Packs were transported to the laboratory on ice and stored at $4^{\circ} \mathrm{C}$ until analysis (no more than $48 \mathrm{~h}$ later).

Filtered water samples (Whatman GF/F) for nutrient analysis were collected in triplicate from each site at each collection. Water samples were analyzed for $\mathrm{NH}_{4}-\mathrm{N}$ (using the phenate method), $\mathrm{NO}_{3}-\mathrm{N}$ (using the cadmium reduction method), and SRP (using the ascorbic acid method) concentration using a Lachat Quickchem flow injection analyzer (Lachat Instruments, Loveland, Colorado, USA; APHA 1999). Samples were also analyzed for dissolved organic carbon (DOC) using a heated persulfate oxidation method (OI Model 1010 Total Organic Carbon Analyzer, CE Elantech, Lakewood, New Jersey, USA; APHA 1999).

\section{Laboratory analysis}

Leaf decomposition rate.-Leaves from each 2 -g pack were dried at $45^{\circ} \mathrm{C}$ for at least $24 \mathrm{~h}$, weighed, ashed at $550^{\circ} \mathrm{C}$ for $2 \mathrm{~h}$, and reweighed in order to obtain ash free dry mass (AFDM). The decomposition rate of sugar maple leaves in each stream was calculated as the slope of the natural logarithm of the percentage of AFDM remaining over time (Benfield 2006).

Fungal biomass.- On each collection date, leaves from the 10 -g packs collected from each stream were pooled and divided into several subsamples. Three replicate paired subsamples of $0.2 \mathrm{~g}$ each were used for ergosterol analysis. One subsample from each pair was placed in 5 $\mathrm{mL}$ of methanol and kept frozen until analysis. Ergosterol was extracted from these samples using a liquid-phase extraction, quantified using high-performance liquid chromatography, and converted to fungal biomass (Gulis and Suberkropp 2006). AFDM was obtained from the remaining subsamples from each pair according to the method described in Leaf decomposition rate. Fungal biomass is expressed as $\mathrm{mg} / \mathrm{g}$ AFDM of detritus.

Detrital $N$ and ${ }^{15} N$ content.-Four subsamples from the 10-g leaf packs of between 15 and $30 \mathrm{mg}$ each were dried at $45^{\circ} \mathrm{C}$ for at least $24 \mathrm{~h}$, ground to a fine powder, and analyzed for $\mathrm{C}$ and $\mathrm{N}$ content using a FlashEA 1112 Series Elemental Analyzer (OI Analytical, College Station, Texas, USA) where samples were combusted at $975^{\circ} \mathrm{C}$ and the products were reduced and measured using a thermal conductivity detector. Four additional subsamples were dried and ground in a similar manner, packaged in tin capsules, and analyzed for ${ }^{15} \mathrm{~N}$ content analysis by mass spectrometry (UC Davis Stable Isotope Facility). All values of ${ }^{15} \mathrm{~N}$ content are expressed in terms of atom fraction or atom $\%$ where

$$
\begin{aligned}
& \text { Atom fraction }={ }^{15} \mathrm{~N}_{\text {sample }} /\left({ }^{15} \mathrm{~N}_{\text {sample }}+{ }^{14} \mathrm{~N}_{\text {sample }}\right) \\
& \text { Atom } \%=\left({ }^{15} \mathrm{~N}_{\text {sample }} /\left({ }^{15} \mathrm{~N}_{\text {sample }}+{ }^{14} \mathrm{~N}_{\text {sample }}\right)\right) \times 100 .
\end{aligned}
$$

Microbial biomass $N$ and ${ }^{15} N$ content.-Additional material from the 10 -g leaf packs was used to determine total $\mathrm{N}$ and ${ }^{15} \mathrm{~N}$ content of the microbial biomass. Microbial $\mathrm{N}$ was isolated from the detritus using chloroform fumigation (Brookes et al. 1985b). This technique has been used extensively in soil ecology and has also been used to extract $\mathrm{N}$ from biofilms associated with leaves in streams (Sanzone et al. 2001). Four 5-g subsamples were fumigated and four 5-g subsamples were left unfumigated for each stream at each collection. Fumigated subsamples were placed in a desiccator with liquid chloroform. The desiccator was sealed, evacuated 
using a vacuum pump to boil the chloroform, and samples were left for $3 \mathrm{~d}$. Fumigated and unfumigated samples were then extracted with $60 \mathrm{~mL}$ of $0.5 \mathrm{~mol} / \mathrm{L}$ $\mathrm{K}_{2} \mathrm{SO}_{4}$. Nitrogen in the extracts was converted to nitrate using the alkaline persulfate oxidation method (Cabrera and Beare 1993). We analyzed $10 \mathrm{~mL}$ of each extractant for $\mathrm{NO}_{3}-\mathrm{N}$ concentration by the cadmium reduction method using a Lachat Quickchem flow injection analyzer. After the removal of the $10-\mathrm{mL}$ subsample, additional $\mathrm{K}_{2} \mathrm{SO}_{4}$ was added to the remaining volume so that each extractant was brought to a volume of $75 \mathrm{~mL}$. To determine the ${ }^{15} \mathrm{~N}$ content of extracted $\mathrm{N}$, nitrate in these samples was converted to ammonia gas by adding Devarda's Alloy and increasing the $\mathrm{pH}$ to $\sim 13$ by adding $2 \mathrm{~mL}$ of $10 \mathrm{~mol} / \mathrm{L} \mathrm{NaOH}$ and trapped on acidified filters (Stark and Hart 1996). Filters were then encapsulated in tin capsules and sent to the University of Nebraska-Lincoln Water Center for ${ }^{15} \mathrm{~N}$ analysis by mass spectrometry.

Microbial total N (TN) was calculated according to the following equation:

$$
\text { Microbial } \mathrm{TN}=\left(\mathrm{N}_{\text {fumigated }}-\mathrm{N}_{\text {unfumigated }}\right) \times 1.61
$$

where $\mathrm{N}_{\text {fumigated }}$ and $\mathrm{N}_{\text {unfumigated }}$ are the mass of total $\mathrm{N}$ extracted from the fumigated and unfumigated samples, respectively, after accounting for the $\mathrm{N}$ load of the $\mathrm{K}_{2} \mathrm{SO}_{4}$ matrix. The factor 1.61 was used to correct for $\mathrm{N}$ that may not have been released from microbial cells during the 3 day fumigation process (Brookes et al. $1985 a, b)$.

The atomic fraction of the microbial biomass $(\mathrm{F}(B))$ was calculated according to the following equation:

$$
\mathrm{F}(B)=\frac{{ }^{15} \mathrm{~N}_{\text {fumigated }}-{ }^{15} \mathrm{~N}_{\text {unfumigated }}}{\mathrm{N}_{\text {fumigated }}-\mathrm{N}_{\text {unfumigated }}}
$$

where ${ }^{15} \mathrm{~N}_{\text {fumigated and }}{ }^{15} \mathrm{~N}_{\text {unfumigated }}$ are the masses of ${ }^{15} \mathrm{~N}$ found on the acidified filters from the fumigated and unfumigated samples, respectively, after accounting for the ${ }^{15} \mathrm{~N}$ load of the $\mathrm{K}_{2} \mathrm{SO}_{4}$ matrix and the Devarda's Alloy.

Leaf-derived microbial N.-The mass of microbial N derived from the leaf substrate at each collection from each stream was calculated as

Microbial $\mathrm{N}$ derived from leaves (\%)

$$
=\frac{\text { microbial } \mathrm{TN} \times[\mathrm{F}(B)-\mathrm{F}(W)]}{\mathrm{F}(L)-\mathrm{F}(W)} \times 100
$$

where $\mathrm{F}(B)$ is the atomic fraction of the microbial biomass, $\mathrm{F}(W)$ is the atomic fraction of the water, and $\mathrm{F}(L)$ is the atomic fraction of the leaf material. $\mathrm{F}(B)$ was measured at each collection. $\mathrm{F}(W)$ was calculated from the mean background stream water atomic fraction observed in the LINX I Appalachian stream sites (Peterson et al. 2001). This value was used for all collections from all sites. We used the leaves collected after $24 \mathrm{~h}$ from each site as a stream-specific $\mathrm{F}(L)$. We assumed that most of the leaching of soluble material occurred during the first $24 \mathrm{~h}$ (Petersen and Cummins 1974) and that there was negligible microbial growth during this time. We also assumed physical, chemical, and biological processing after $24 \mathrm{~h}$ did not further change the isotopic signature of the leaf material itself.

Patterns along the $\mathrm{NO}_{3}{ }^{-}$gradient.-Because of differences in leaf decomposition rates among the five streams, we assessed patterns in detrital $\mathrm{C}: \mathrm{N}$, microbial $\mathrm{TN}$, detrital and microbial biomass isotopic signatures, and the percentage of leaf-derived $\mathrm{N}$ across the gradient of $\mathrm{NO}_{3}^{-}$availability by establishing linear relationships between these variables and percentage of AFDM remaining in each site. Using these relationships, we calculated the values of each response variable from each site at 90\%, 75\%, and 50\% AFDM remaining. These relationships were generally tight $\left(r^{2}=0.196-\right.$ 0.973 ) with the exception of the microbial atom $\%$ and percentage of leaf-derived $\mathrm{N}$ in $\mathrm{SC}\left(r^{2}<0.006\right)$. We then assessed patterns in these variables over the mean water column $\mathrm{NO}_{3}-\mathrm{N}$ concentration.

\section{Statistics}

All statistical tests were conducted using SigmaPlot with SigmaStat Integration (version 10; Systat Software, Chicago, Illinois, USA) except for the ANCOVA and mixed model tests, which were performed in JMP (version 9.0.0; SAS Institute, Cary, North Carolina, USA).

Stream parameters.- Stream characteristic including mean $\mathrm{NO}_{3}-\mathrm{N}, \mathrm{NH}_{4}-\mathrm{N}, \mathrm{SRP}$, and DOC concentrations and temperature were compared among sites using oneway analysis of variance (ANOVA) with Tukey post hoc pair-wise comparisons.

Detrital parameters. - Peak and final fungal biomass were also compared among sites using one-way ANOVA with Tukey post hoc pair-wise comparisons. Changes in the natural log of percentage of AFDM remaining over time were compared among sites using analysis of covariance (ANCOVA) with site as the categorical variable and days in stream as the covariate. The pattern of decomposition rates across the $\mathrm{NO}_{3}-\mathrm{N}$ gradient was assessed using linear regression. Relationships among decomposition rate and fungal biomass were determined using Pearson correlations while linear regressions were used to determine changes in detrital $\mathrm{C}: \mathrm{N}$, detrital percent $\mathrm{N}$, and microbial $\mathrm{TN}$ with percentage of AFDM remaining. The value of $0.01 \mu \mathrm{g}$ $\mathrm{NO}_{3}-\mathrm{N} / \mathrm{L}$ was used if $\mathrm{NO}_{3}-\mathrm{N}$ concentrations were below detection.

$N$ source comparisons.-Linear regression was also used to determine patterns in detrital atom \%, microbial atom fraction, and the percentage of microbial $\mathrm{N}$ from leaves over the course of decomposition. Microbial atom fractions were arcsine-squareroot transformed to meet the assumptions of normality. The rate of change in isotopic signatures were analyzed using ANCOVA, with the percentage of 
TABLE 1. Stream characteristics for each study site listed in order of increasing $\mathrm{NO}_{3}-\mathrm{N}$ concentration.

\begin{tabular}{|c|c|c|c|c|c|c|c|}
\hline \multirow[b]{2}{*}{ Site } & \multicolumn{2}{|c|}{ Decomposition rate } & \multirow[b]{2}{*}{ Temperature $\left({ }^{\circ} \mathrm{C}\right)$} & \multirow[b]{2}{*}{$\mathrm{NO}_{3}-\mathrm{N}(\mu \mathrm{g} / \mathrm{L})$} & \multirow[b]{2}{*}{$\mathrm{NH}_{4}-\mathrm{N}(\mu \mathrm{g} / \mathrm{L})$} & \multirow[b]{2}{*}{$\operatorname{SRP}(\mu \mathrm{g} / \mathrm{L})$} & \multirow[b]{2}{*}{$\mathrm{DOC}(\mu \mathrm{g} / \mathrm{L})$} \\
\hline & $\left(\mathrm{d}^{-1}\right)$ & $\overline{\left(\text { degree-day }^{-1}\right)}$ & & & & & \\
\hline HW & $0.0028^{\mathrm{a}}$ & $0.00037^{\mathrm{a}}$ & $8.08^{\mathrm{a}}(2.83$ & $\mathrm{bd}^{\mathrm{a}}(\mathrm{bd})$ & $3.8(\mathrm{bd}$ & $\mathrm{bd}^{\mathrm{a}}(\mathrm{bd}-3.2)$ & $754^{\mathrm{a}}(461-1384)$ \\
\hline LS & $0.0041^{\mathrm{b}}$ & $0.00065^{\mathrm{b}}$ & $6.18^{\mathrm{b}}(4.10-9.52)$ & $9.2^{\mathrm{a}}(\mathrm{bd}-15.3)$ & $5.5(1.2-15.4)$ & $\mathrm{bd}^{\mathrm{a}}(\mathrm{bd}-4.7)$ & $2097^{\mathrm{b}}(1627-2602)$ \\
\hline LB & $0.0057^{\mathrm{b}}$ & $0.00092^{\mathrm{b}}$ & $5.18^{\mathrm{c}}(0.671-10.7)$ & $164.1^{\mathrm{b}}(53.6-225)$ & $5.6(1.8-14.3)$ & $6.3^{\mathrm{b}}(\mathrm{bd}-16.6)$ & $1385^{\mathrm{c}}(897-1803)$ \\
\hline $\mathrm{SC}$ & $0.0057^{\mathrm{b}}$ & $0.00074^{\mathrm{b}}$ & $7.41^{\mathrm{a}}(2.36-11.5)$ & $358.6^{\mathrm{b}}(94.2-704)$ & 7.1 (bd-14.7) & $10.5^{\mathrm{c}}(5.0-13.9)$ & $1456^{\mathrm{c}}(1074-2325)$ \\
\hline SM & $0.0089^{\mathrm{b}}$ & $0.00110^{\mathrm{b}}$ & $7.37^{\mathrm{a}}(4.26-12.5)$ & $1396^{\mathrm{c}}(1107-1650)$ & $12.2($ bd-36.9) & $6.3^{\mathrm{ab}}(\mathrm{bd}-16.8)$ & $2039^{\mathrm{b}}(1641-2398)$ \\
\hline
\end{tabular}

Notes: Temperature and chemistry values are means with range in parentheses. Different superscript letters after means indicate significant differences $(P<0.05)$ among sites (ANCOVA for decomposition rates and ANOVA for chemistry). Values shown as "bd" are below detection.

AFDM remaining as a continuous variable and site as a categorical variable. Patterns in detrital $\mathrm{C}: \mathrm{N}$, microbial $\mathrm{TN}$, detrital atom $\%$, microbial atom $\%$, and percentage of $\mathrm{N}$ from leaves across the $\mathrm{N}$ gradient were determined using linear regressions of each variable calculated at $90 \%, 75 \%$, and $50 \%$ AFDM remaining vs. mean $\mathrm{NO}_{3}-\mathrm{N}$ concentration. The slopes of these regressions were compared within each variable using a mixed model analysis with stream $\mathrm{NO}_{3}-\mathrm{N}$ as a continuous variable and percentage of AFDM remaining $(90 \%, 75 \%$, and $50 \%)$ as a categorical variable.

\section{RESUlts}

\section{Stream chemistry}

Concentrations of $\mathrm{NO}_{3}-\mathrm{N}$ differed consistently across the five sites (Table 1) with the greatest $\mathrm{NO}_{3}-\mathrm{N}$ concentrations in $\mathrm{SM}$, intermediate concentrations in SC and LB, and low concentrations in HW and LS (oneway ANOVA; $P<0.001)$. Other nutrients also varied among sites (Table 1). Mean $\mathrm{NH}_{4}-\mathrm{N}$ and SRP concentrations were less than $13 \mu \mathrm{g} / \mathrm{L}$ in all sites. Mean $\mathrm{NH}_{4}-\mathrm{N}$ did not differ among sites (one-way ANOVA, $P=0.14$ ). Mean SRP concentration was greatest in SC, lowest in $\mathrm{HW}$ and LS, and intermediate in LB and SM (one-way ANOVA, $P<0.001)$. Mean DOC also varied spatially with the lowest concentrations in $\mathrm{HW}$, intermediate levels in $\mathrm{LB}$ and $\mathrm{SC}$, and the greatest concentrations in LS and SM (one-way ANOVA, $P<0.001$ ). Sites differed in temperature by $\sim 3^{\circ} \mathrm{C}$ (Table 1 ). LB was significantly cooler than the other sites and HW, SC, and SM were significantly warmer (one-way ANOVA; $P$ $<0.001)$.

\section{Sugar maple breakdown rates and fungal biomass}

Decomposition rate ranged from 0.0028 to $0.0089 \mathrm{~d}^{-1}$ (Table 1). Decomposition rate increased with $\mathrm{NO}_{3}{ }^{-}$ availability (linear regression; $r^{2}=0.866, P=0.022$ ). Leaves in $\mathrm{HW}$, the stream with the lowest $\mathrm{NO}_{3}-\mathrm{N}$ concentration, decomposed $1.5-3 \times$ slower than leaves at the other sites (Table 1; ANCOVA, $P=0.005$ ) even though this stream had the highest temperature. $\mathrm{NO}_{3}-\mathrm{N}$ concentration explained over $60 \%$ of the variation in decomposition rate calculated per degree-day among sites, although this relationship was not statistically significant (Table 1, linear regression; $r^{2}=0.620, P=$ 0.114).

Fungal biomass generally peaked between 15 and 60 days in all sites, with the exception of LB, where fungal biomass was still increasing at the end of the study (Fig. 2). Both peak and final fungal biomass were similar among sites (one-way ANOVA, $P>0.304$ ). Neither peak nor final fungal biomass were correlated with sugar maple decomposition rates (Pearson correlation, $r=0.448, P=0.449$ and $r=0.307, P=0.616$, respectively).

\section{$N$ pools during decomposition}

Microbial $\mathrm{N}$ dynamics were strongly linked to the progression of decomposition. Both detrital and microbial $\mathrm{N}$ content varied as a function of the percentage of AFDM remaining. Detrital C: $\mathrm{N}$ decreased after $24 \mathrm{~h}$ in all sites and continued to decrease as decomposition progressed, with the percentage of AFDM remaining explaining $48 \%$ of the variation in molar C:N (linear regression; $r^{2}=0.481, P<0.001$; Fig. 3A). Detrital $N$ (expressed as percentage of detrital AFDM) remained above initial values in all sites except HW (Fig. 3B) and generally increased over the course of decomposition, although this relationship was not statistically significant (linear regression; $r^{2}=0.112, P=0.119$ ). This increase in detrital $\mathrm{N}$ was reflected in the microbial $\mathrm{TN}$, which increased linearly as decomposition progressed (linear regression; $r^{2}=0.601, P<0.001$; Fig. 3C).

Isotopic signatures of both the detritus and the microbial biomass were also strongly related to stage of decomposition. Both detrital and microbial ${ }^{15} \mathrm{~N}$ signatures decreased as leaves lost mass (Fig. 4A, B). When all sites were analyzed together, the percentage of AFDM remaining explained over $55 \%$ of the variance in detrital atom $\%$ (linear regression; $r^{2}=0.552, P<0.001$ ) and over $37 \%$ of the variance in microbial atom fraction (linear regression; $r^{2}=0.376, P=0.003$ ). Patterns in detrital and microbial isotopic signature decline were similar among streams with the exception of SC, which declined more slowly than the other sites (ANCOVA, $P$ $=0.0007$ and $P=0.0118$, respectively). All observed values of detrital atom $\%$ and microbial atomic fraction were between those of the dry leaves before incubation (atom $\%=0.8653 \pm 0.0941[$ mean $\pm \mathrm{SD}]$ ) and the water 


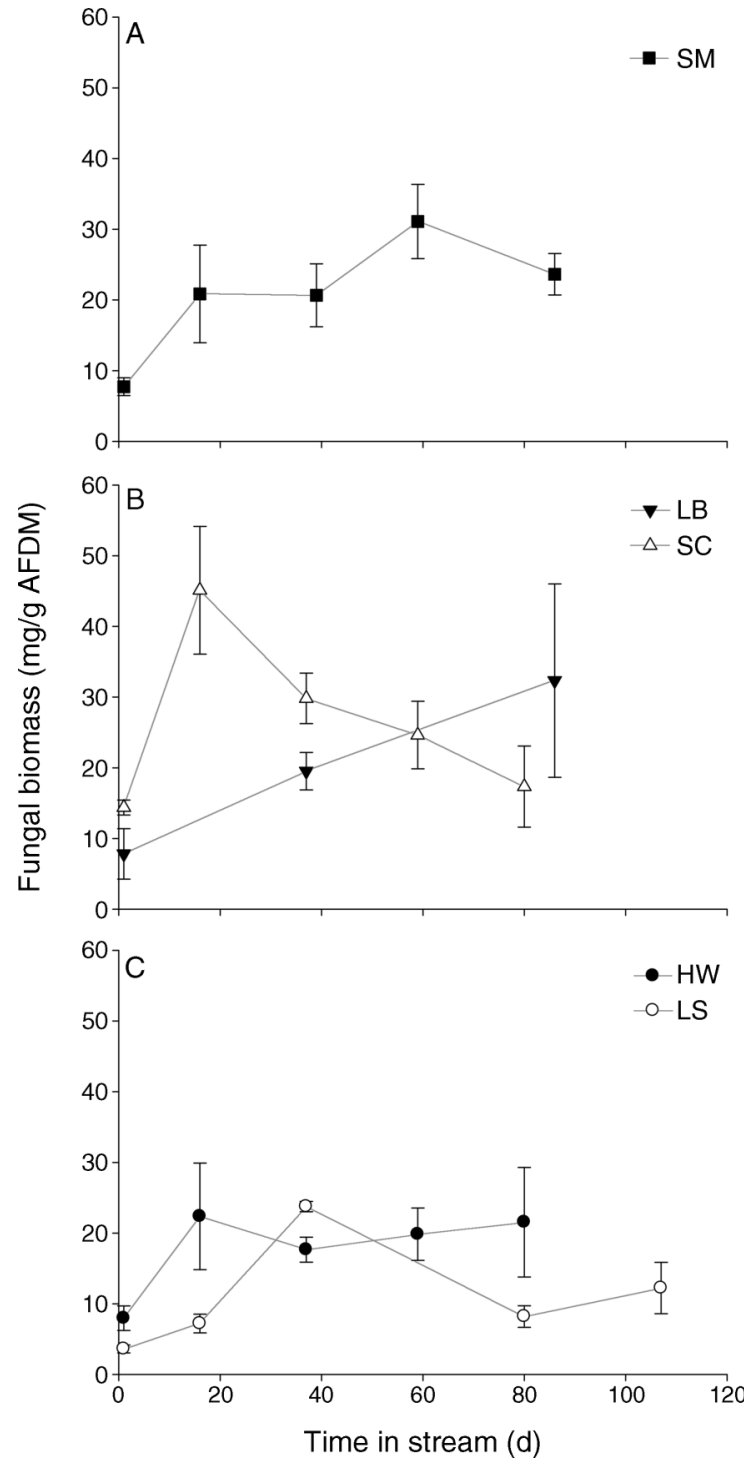

FIG. 2. Fungal biomass (mg/g ash-free dry mass [AFDM]; mean $\pm \mathrm{SE}$ ) of detritus collected from (A) high, (B) medium, and (C) low $\mathrm{N}$ streams over time. Sample size was $n=3$ replicates for each collection from each site.

(atom $\%=0.3660 \pm 0.004$ ), with the exception of the microbial atom fraction of the first collection from HW, which was greater than that of the dry leaves before incubation and was therefore excluded from this and further analyses.

Microbial sources of $\mathrm{N}$ shifted over the course of decomposition (Fig. 4C). The percent of leaf-derived N in the microbial biomass declined in each individual site, again with the exception of SC. When analyzed together, the percentage of microbial $\mathrm{N}$ derived from the leaves decreased linearly during decomposition (linear regression; $r^{2}=0.332$. $P=0.008$; Fig. 4 C).
$\mathrm{N}$ pools over $\mathrm{NO}_{3}^{-}$gradient

Differences in $\mathrm{N}$ and ${ }^{15} \mathrm{~N}$ content among sites were strongly dependent on the stage of decomposition, not $\mathrm{NO}_{3}^{-}$availability. $\mathrm{NO}_{3}^{-}$availability did not significantly alter detrital C:N (mixed model, $P=0.089$ ) or microbial TN (mixed model; $P=0.471$ ) at $90 \%, 75 \%$, and 50\% AFDM remaining (Fig. 5A and B). However,
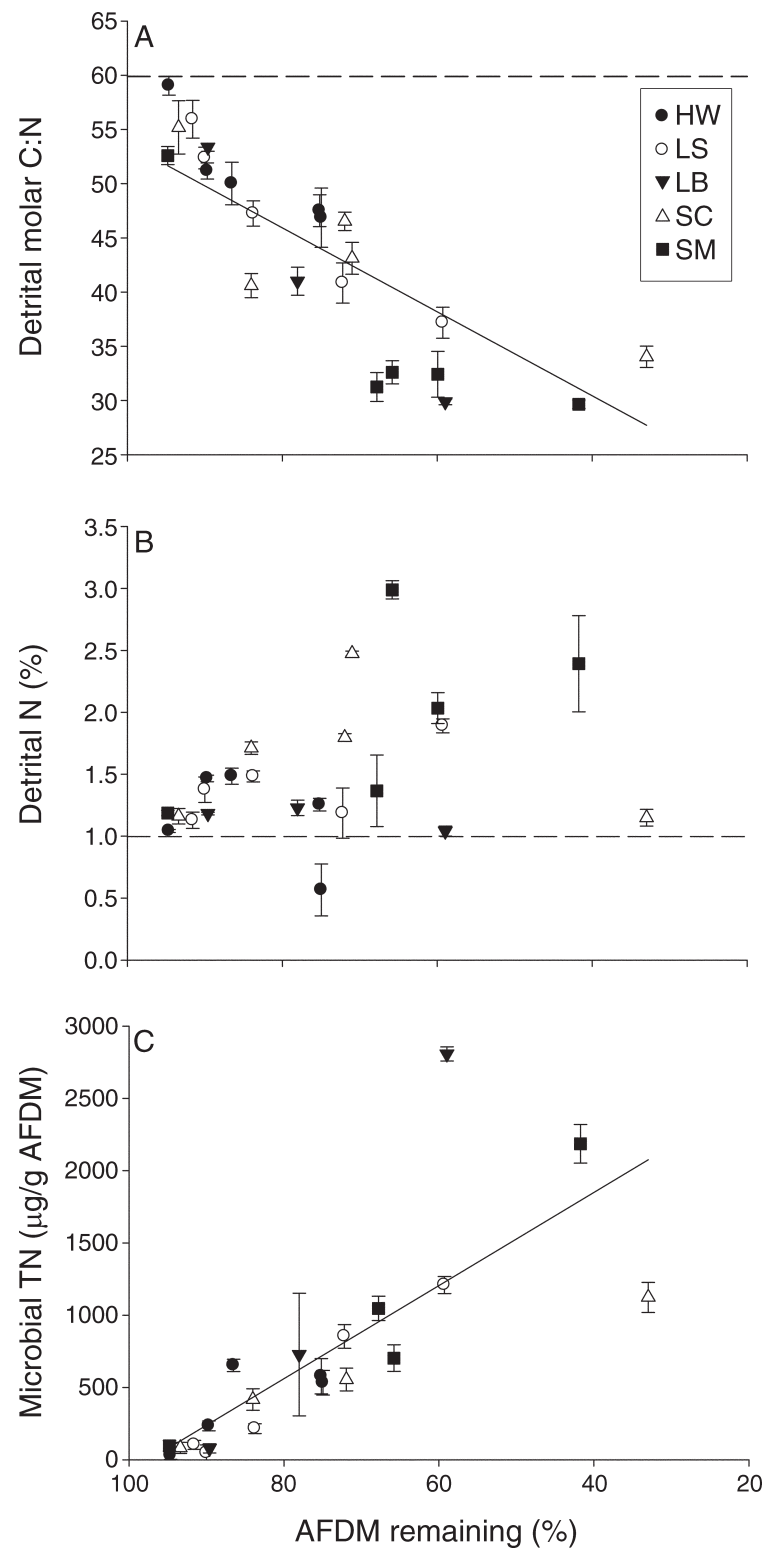

FIG. 3. Changes in detrital and microbial $\mathrm{N}$ content as a function of extent of decomposition. Error bars in panels (A) and (B) are \pm SE, while error bars in panel (C) are $\pm 95 \%$ confidence intervals. The dashed lines in panels (A) and (B) represent the condition of leaves before deployment, and solid lines are linear regressions including all sites with $\mathrm{C}: \mathrm{N}=0.387 \times$ AFDM remaining +14.961 and microbial total $\mathrm{N}(\mathrm{TN})=$ $-32.202 \times$ AFDM remaining +3137.561 . Note that AFDM decreases from left to right along the $x$-axis. Detrital $\% \mathrm{~N}$ is expressed as a percentage of detrital AFDM. 

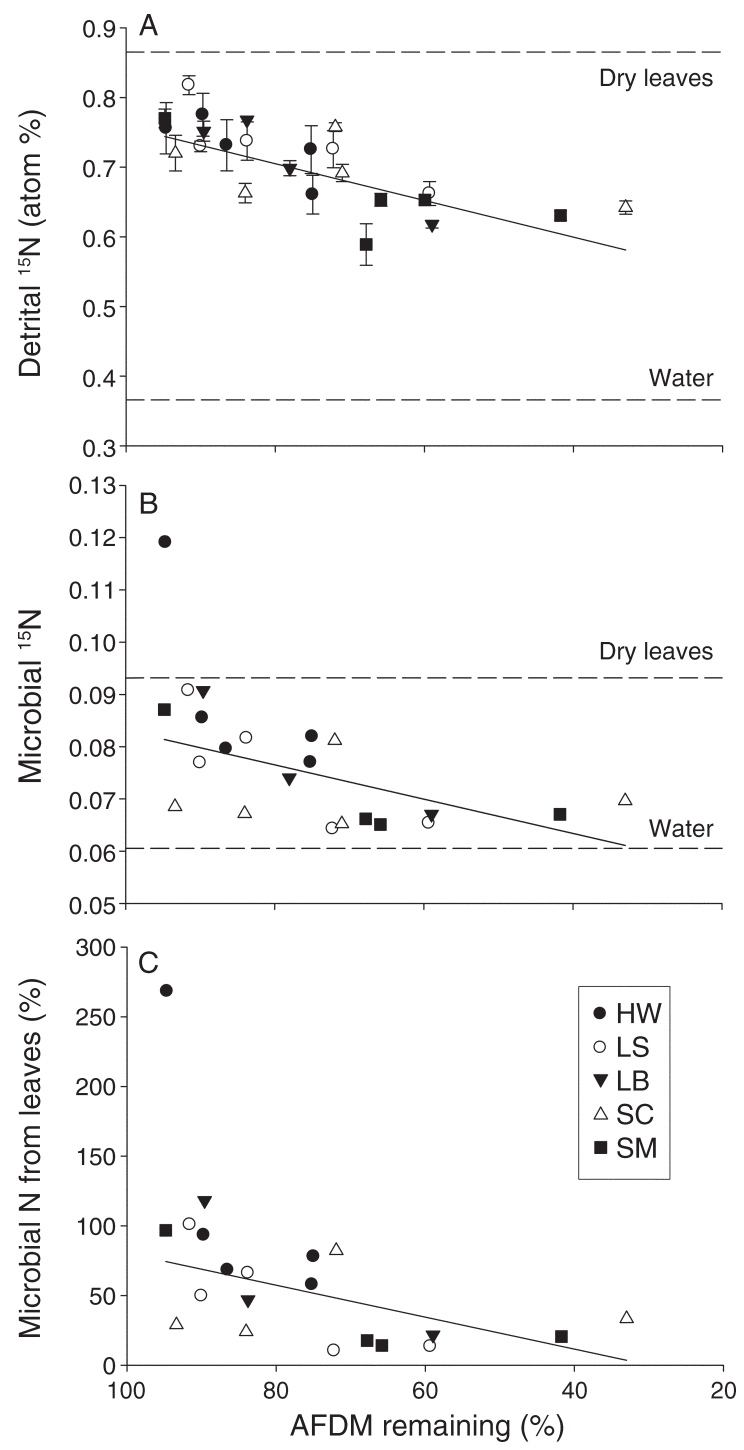

FIG. 4. Relative ${ }^{15} \mathrm{~N}$ abundance in (A) detritus and (B) microbial biomass (arcsine-square-root transformed; originally measured as atom fraction) and (C) the percentage of microbial $\mathrm{N}$ derived from leaves over decomposition in each site. Values in panel (A) are means $\pm \mathrm{SE}$ of four samples. Solid lines are regressions with detrital atom $\%=0.00265 \times$ AFDM remaining +0.505 , microbial atom fraction (arcsine-square-root transformed $)=0.000328 \times \mathrm{AFDM}$ remaining +0.0503 , and percentage of microbial $\mathrm{N}$ from leaf $=1.146 \times \mathrm{AFDM}$ remaining -34.326 . Regressions in panels (B) and (C) exclude the first collection from HW. Dashed lines in panels (A) and (B) are the values of leaves before deployment (upper line) and of stream water (lower line). Note that AFDM decreases from left to right along the $x$-axis.

both detrital C:N and microbial TN changed significantly as the percentage of AFDM remaining declined, decreasing (mixed model; $P=0.0002$ ) and increasing (mixed model; $P=0.011$ ), respectively. The isotopic signatures of detritus and microbial biomass tended to decrease with greater $\mathrm{NO}_{3}{ }^{-}$availability, but these trends were not statistically significant (mixed model; $P>$
0.277; Fig. 5C and D). The proportion of leaf-derived N in the microbial biomass did not respond to $\mathrm{NO}_{3}{ }^{-}$ availability (mixed model; $P=0.956$; Fig. 5E). In contrast, both the detrital and microbial atom fraction significantly decreased as decomposition progressed (mixed model; $P<0.013$ ), as did the percentage of leaf-derived $\mathrm{N}$ in microbial biomass (mixed model; $P=$ 0.016).

\section{Discussion}

Organic matter decomposition occurs in three main phases: the leaching phase where soluble compounds are lost via chemical leaching, the conditioning phase where microbes colonize detritus and mineralize carbon, and the animal-processing phase (Petersen and Cummins 1974). Heterotrophic microbial assemblages develop in the context of this temporal continuum. Our study provides empirical data, which we present as a conceptual model (Fig. 6), describing the tight relationship between microbial $\mathrm{N}$ cycling and decomposition processes.

Nearly $100 \%$ of the initial microbial $\mathrm{N}$ was assimilated from leaves in four out of five sites in our study. We propose that microbes initially acquire leaf-derived $\mathrm{N}$, perhaps from highly labile, leached materials, as they become established on detrital surfaces, resulting in assimilation as a dominant flux and a corresponding high proportion of leaf-derived $\mathrm{N}$ in microbial biomass during the first $24 \mathrm{~h}$ of decomposition. By the end of our study, the percentage of microbial $\mathrm{N}$ derived from the leaves had decreased to $10-20 \%$ in the majority of our sites, indicating an increased reliance on exogenous $\mathrm{N}$ to support microbial growth. This increased importance of immobilization was clearly demonstrated in our study by the consistent decline in the isotopic signature of both the detritus and the microbial biomass as percentage of AFDM remaining decreased (Fig. 4). However, it is important to note that microbial $\mathrm{N}$ in $\mathrm{HW}$, our lowest DIN site, was still composed of over $75 \% \mathrm{~N}$ from the leaves (Fig. 4). Therefore, we propose that although the importance of substrate $\mathrm{N}$ declines over the course of decomposition, assimilation continues to occur and support microbial growth.

Although we did not assess immobilization and assimilation during the later stages of decomposition (leaves in our study still had at least 30\% AFDM remaining at the final collection), other studies suggest that microbes switch from net immobilization to net mineralization at some point and the timing of this shift is dependent on the stoichiometry of the microbes compared to the remaining detritus (Moore et al. 2006, Manzoni et al. 2008, 2010). Therefore, we show peak immobilization during the net microbial growth phase in our model.

DIN availability did not appear to affect nutrient dynamics directly in our study. Fungal biomass did not differ among our sites and the relative proportion of leaf and water-derived $\mathrm{N}$ responded more strongly to stage 

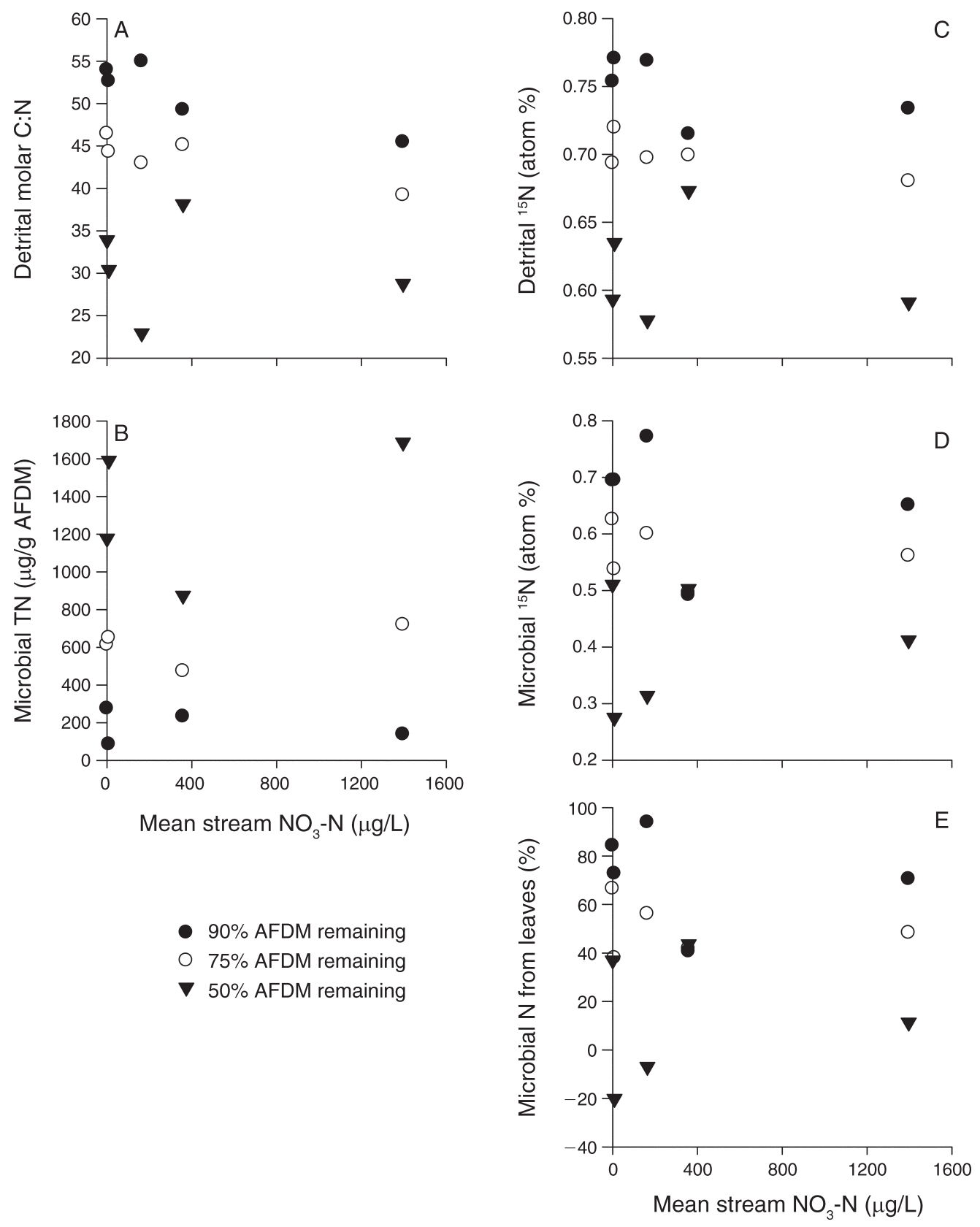

FIG. 5. (A) Detrital C:N, (B) microbial TN, (C) detrital ${ }^{15} \mathrm{~N}$, (D) microbial ${ }^{15} \mathrm{~N}$, and (E) the percentage of microbial $\mathrm{N}$ from leaves with $90 \%, 75 \%$, and $50 \%$ AFDM remaining across the gradient in $\mathrm{NO}_{3}{ }^{-}$availability. Water column $\mathrm{NO}_{3}-\mathrm{N}^{-}$is the mean $\mathrm{NO}_{3}-$ $\mathrm{N}$ concentration over the entire study. Data were calculated from linear relationships between each variable and percentage of AFDM remaining in each site.

of decomposition than to $\mathrm{N}$ availability. These results agree with Parton et al. (2007), who showed that mass loss and substrate nutrient content were more important than site-specific variables in determining nutrient cycling during terrestrial organic matter decomposition. However, our findings are in contrast to several studies that have shown microbial responses to experimental DIN enrichment. Gulis and Suberkropp (2003) showed significantly greater fungal biomass and higher micro- bial respiration rates in stream reaches enriched with nitrogen and phosphorus on two different leaf litter types compared to upstream control reaches. Suberkropp et al. (2010) showed similar responses of microbial activity on a per gram substrate basis to a long-term $\mathrm{N}$ and $\mathrm{P}$ enrichment. The lack of response in fungal biomass to the $\mathrm{NO}_{3}{ }^{-}$gradient in our study is particularly peculiar as leaf breakdown rate was positively related to $\mathrm{NO}_{3}^{-}$availability. It is important 


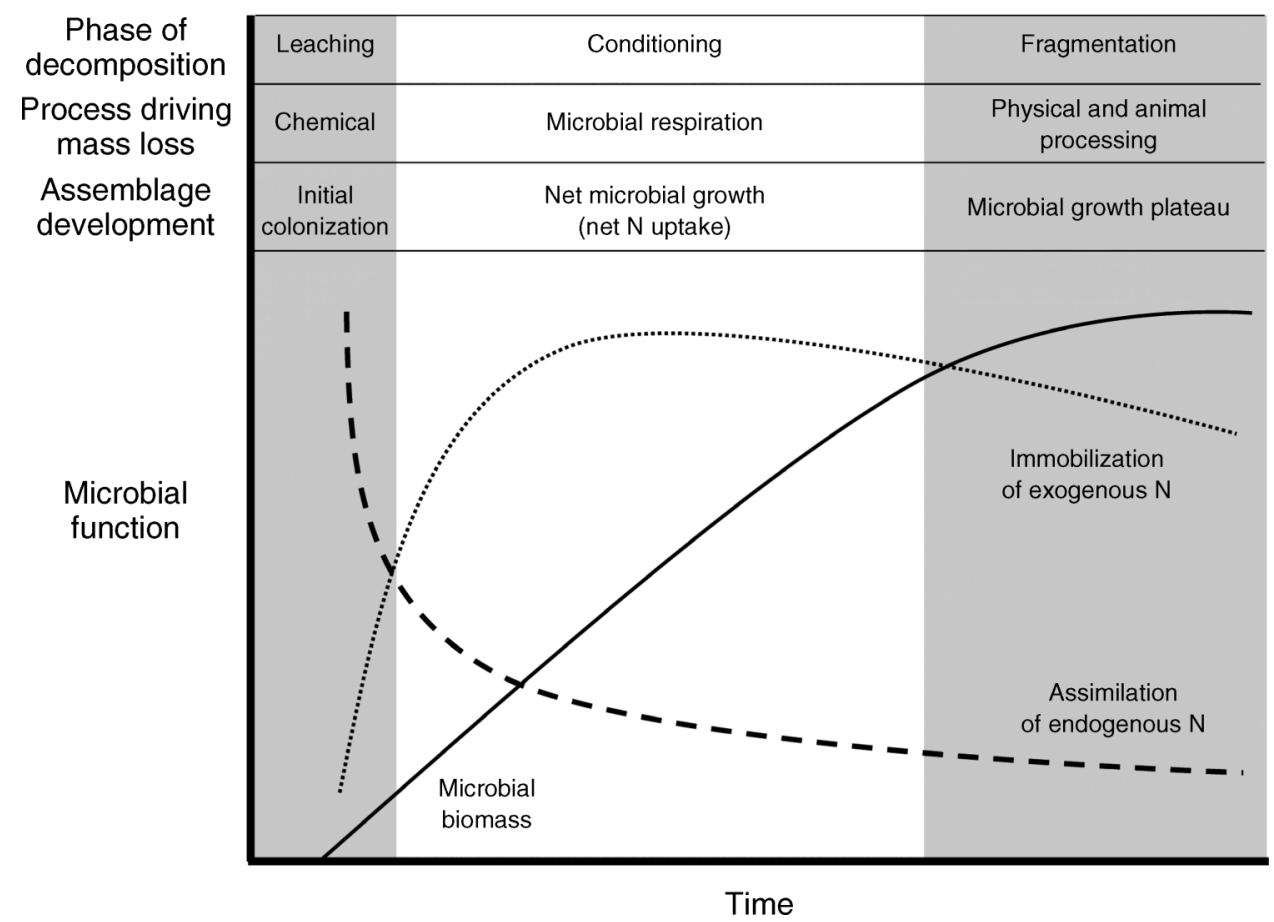

FIG. 6. Conceptual model describing changes in microbial functions including immobilization of exogenous $\mathrm{N}$ (dotted line) and assimilation of endogenous $\mathrm{N}$ (dashed line) as microbial biomass (solid line) develops over the course of decomposition. Top panels provide stage of decomposition, mass loss processing, and microbial assemblage development context. Stage of decomposition and processes are adapted from Petersen and Cummins (1974).

to note that microbial biomass may not reflect production. Leaves from high $\mathrm{N}$ streams may have supported microbial assemblages with a greater percentage of bacteria, which have a faster turnover rate compared to fungi and this may have contributed to a faster decomposition rate.

\section{Consequences for organic matter decomposition}

The relative importance of exogenous $\mathrm{N}$ and substrate-derived $\mathrm{N}$ pools in meeting microbial growth requirements has implications for organic matter decomposition, particularly with the anthropogenic acceleration of the global $\mathrm{N}$ cycle. $\mathrm{N}$ enrichment is expected to increase decomposition rates if microbes use exogenous $\mathrm{N}$ sources. However, if microbes use substrate $\mathrm{N}$, $\mathrm{N}$ enrichment may decrease decomposition rates as microbes shift to this more labile pool (Carreiro et al. 2000, Moorhead and Sinsabaugh 2006, Craine et al. 2007).

We have shown that immobilization of DIN is an important flux, even when DIN availability is relatively low. Sugar maple decomposition in our streams occurred more rapidly as $\mathrm{NO}_{3}-\mathrm{N}$ concentration increased, supporting the prediction that increasing exogenous $\mathrm{N}$ availability may lead to increased microbial activity. Decomposition rates in our study were measured in fine mesh bags and are much lower than typical maple leaf breakdown rates where mesh size is large enough for invertebrate access to the leaves (e.g., Webster et al. 1999) but still allow for comparisons across the $\mathrm{NO}_{3}^{-}$gradient.

Our results agree with studies in both terrestrial and freshwater ecosystems showing faster decomposition with increased nutrient availability (e.g., Hunt et al. 1988, Hobbie 2000, Vestgarden 2001, Gulis and Suberkropp 2003, although see Triska and Sedell 1976, Newbold et al. 1983, Magill and Aber 1998, Hobbie and Vitousek 2000), including a recent study by Woodward et al. (2012) that showed that the response of organic matter decomposition to nutrient availability in streams is not linear but is fastest at intermediate concentrations. Using 100 European streams across a 1000-fold nutrient gradient, Woodward et al. (2012) found maximum decomposition rates in streams with DIN concentrations above $1000 \mu \mathrm{g} / \mathrm{L}$ and SRP concentrations above $\sim 20$ $\mu \mathrm{g} / \mathrm{L}$. The positive relationship between sugar maple decomposition rate and $\mathrm{NO}_{3}{ }^{-}$availability in our study adheres to this pattern and supports their supposition of microbial nutrient limitation at low nutrient concentrations. All of our streams had SRP concentrations less than $10 \mu \mathrm{g} / \mathrm{L}$ and only SM had DIN concentrations slightly higher than $1000 \mu \mathrm{g} / \mathrm{L}$, which places them on the rising portion of the Woodward et al. (2012) unimodal curve. We suggest that continued $\mathrm{N}$ enrichment may result in an acceleration of carbon processing in ecosystems with relatively low ambient $\mathrm{N}$ availability. 


\section{Avenues for additional research}

Our model provides a description of $\mathrm{N}$ cycling by heterotrophic microbes during leaf decomposition and generates many interesting questions. We see several particularly fruitful avenues for further study. First, the composition of the microbial assemblage likely has implications for our model. We conceptualized the microbial assemblage as a "black-box" with a uniform $\mathrm{N}$ requirement, dominant function (i.e., immobilization of exogenous $\mathrm{N}$ or assimilation of substrate $\mathrm{N}$ ), and response to exogenous $\mathrm{N}$ availability. However, the leafassociated microbial biomass contains a diverse assemblage of organisms (Suberkropp and Klug 1976), and the increasing reliance on water-derived $\mathrm{N}$ described by our model may not be solely due to a functional shift from assimilation to immobilization but may also reflect a compositional shift in the microbial assemblage. Fungi dominate microbial biomass in the early stages of decomposition (Suberkropp and Klug 1976, Weyers and Suberkropp 1996) and produce exoenzymes that metabolize leaf compounds (Suberkropp and Klug 1980, Chamier 1985) and therefore may be able to better utilize $\mathrm{N}$ bound in these compounds. Bacterial biomass and production are low during the early stages of decomposition but can exceed fungi on smaller more processed fragments (Sinsabaugh and Findlay 1995) and may rely more heavily on immobilization of exogenous DIN. Although it is unlikely that decomposition had progressed far enough for bacteria to dominate the microbial assemblages in any of our sites (Gulis and Suberkropp 2003), it is possible that smaller fragments with high bacterial abundance were trapped in the leaf packs and were included as part of the detritus. If so, the depletion of the ${ }^{15} \mathrm{~N}$ signature and the decrease in the proportion of leaf-derived $\mathrm{N}$ in the microbial biomass may have been due to an increasing influence of bacterial activity. Characterizing the microbial assemblage (i.e., fungi vs. bacterial abundance and production, active vs. inactive biomass, enzyme production) over the course of decomposition may lend insight to the mechanisms causing the patterns described by our model.

Second, our model is a hypothesis that needs to be tested across ecosystem types. The immobilization of exogenous $\mathrm{N}$ is likely important in all ecosystems due to the stoichiometric imbalance between microbial biomass and detritus common in many systems (Sterner and Elser 2002, Manzoni et al. 2010). However, exogenous N availability may play a stronger role in ecosystems without continuous advective flow. While biological uptake can lower stream water nutrient concentration during periods of peak microbial activity (Mulholland and Hill 1997), flow from upstream provides a consistent source of nutrients. In contrast, exogenous $\mathrm{N}$ in terrestrial ecosystems is dependent on precipitation regime and the hydrologic storage capacity of the litter layer. Exogenous $\mathrm{N}$ in lentic ecosystems may be abundant, particularly in eutrophic systems, but this pool may become depleted during some times of the year, which may limit immobilization. Microbes in this situation may increase $\mathrm{N}$ assimilation or may experience $\mathrm{N}$ limitation. Exogenous $\mathrm{N}$ availability may play a more important role in driving the interactions between endogenous and exogenous nutrient sources in these ecosystems compared to what we observed in streams.

Finally, the labeled substrate method that we used here provides a novel way of investigating the response of organic matter decomposition to nutrient enrichment across ecosystems. We propose that experiments combining this method with direct manipulations of the exogenous $\mathrm{N}$ pool would address not only the response of organic matter decomposition to increased $\mathrm{N}$ availability but would also provide a mechanistic understanding of the microbial processes involved in coupling $\mathrm{N}$ and $\mathrm{C}$ cycling.

\section{ACKNOWLedgments}

Special thanks to Adam Hart for contributing to the fieldwork and laboratory analysis as part of his undergraduate research program at Virginia Tech. This work was supported by the National Science Foundation through the Coweeta LongTerm Ecological Research Project (DEB-0823293 and DEB02218001) and a Doctoral Dissertation Improvement Grant (DEB-478406). We are grateful to the Fahey Lab at Cornell University for providing the labeled leaves. Laura Stanley, Julia Campus, Jeffrey Norman, and Bobbie Niederlehner assisted with sample collection and processing. We also thank Kathi Susano and Kenneth Godboy for access to Smith Creek, and Fred Benfield, Maury Valett, Jeb Barrett, Andy Dolloff, and the Virginia Tech Stream Team and Ecosystem Research Group for their contributions to the development of this project. This manuscript was improved by comments from Jeb Barrett, Maury Valett, and two anonymous reviewers.

\section{Literature Cited}

Aber, J. D., and J. M. Melillo. 1982. Nitrogen immobilization in decaying hardwood leaf litter as a function of initial nitrogen and lignin content. Canadian Journal of Botany 60: 2263-2269.

APHA. 1999. Standard methods for the examination of water and wastewater. 20th edition. American Public Health Association, American Water Works Association, and Water Environment Federation, Washington, D.C., USA.

Benfield, E. F. 2006. Decomposition of leaf material. Pages 711-720 in F. R. Hauer and G. A. Lamberti, editors. Methods in stream ecology. Academic Press, Amsterdam, The Netherlands.

Berg, B., A. V. De Santo, F. A. Rutigliano, A. Fierro, and G. Ekbohm. 2003. Limit values for plant litter decomposing in two contrasting soils - influence of litter elemental composition. Acta Oecologica International Journal of Ecology 24: 295-302.

Berg, B., and C. McClaugherty. 1989. Nitrogen and phosphorus release from decomposing litter in relation to the disappearance of lignin. Canadian Journal of Botany 67: $1148-1156$

Brookes, P. C., J. F. Kragt, D. S. Powlson, and D. S. Jenkinson. 1985a. Chloroform fumigation and the release of soil-nitrogen - the effects of fumigation time and temperature. Soil Biology and Biochemistry 17:831-835.

Brookes, P. C., A. Landman, G. Pruden, and D. S. Jenkinson. 1985b. Chloroform fumigation and the release of soilnitrogen - a rapid direct extraction method to measure 
microbial biomass nitrogen in soil. Soil Biology and Biochemistry 17:837-842.

Cabrera, M. L., and M. H. Beare. 1993. Alkaline persulfate oxidation for determining total nitrogen in microbial biomass extracts. Soil Science Society of America Journal 57:10071012.

Carreiro, M. M., R. L. Sinsabagh, D. A. Repert, and D. F. Parkhurst. 2000. Microbial enzyme shifts explain litter decay responses to simulated nitrogen deposition. Ecology 81:23592365.

Carter, M. D., and K. Suberkropp. 2004. Respiration and annual fungal production associated with decomposing leaf litter in two streams. Freshwater Biology 49:1112-1122.

Chamier, A. C. 1985. Cell-wall-degrading enzymes of aquatic hyphomycetes - a review. Botanical Journal of the Linnaean Society 91:67-81.

Cheever, B. M., E. B. Kratzer, and J. R. Webster. 2012. Immobilization and mineralization of $\mathrm{N}$ and $\mathrm{P}$ by heterotrophic microbes during leaf decomposition. Freshwater Science 31:133-147.

Craine, J. M., C. Morrow, and N. Fierer. 2007. Microbial nitrogen limitation increases decomposition. Ecology 88: 2105-2113.

Das, M., T. V. Royer, and L. G. Leff. 2007. Diversity of fungi, bacteria, and actinomycetes on leaves decomposing in a stream. Applied and Environmental Microbiology 73:756767.

Eggert, S. L., and J. B. Wallace. 2003. Litter breakdown and invertebrate detritivores in a resource-depleted Appalachian stream. Archiv für Hydrobiologie 156:315-338.

Fahey, T. J., J. B. Yavitt, R. E. Sherman, P. M. Groffman, M. C. Fisk, and J. C. Maerz. 2011. Transport of carbon and nitrogen between litter and soil organic matter in a northern hardwood forest. Ecosystems 14:326-340.

Finzi, A. C., A. T. Austin, E. E. Cleland, S. D. Frey, B. Z. Houlton, and M. D. Wallenstein. 2011. Responses and feedbacks of coupled biogeochemical cycles to climate change: examples from terrestrial ecosystems. Frontiers in Ecology and the Environment 9:61-67.

Fisher, S. G., and G. E. Likens. 1973. Energy flow in Bear Brook New Hampshire: an integrative approach to stream ecosystem metabolism. Ecological Monographs 43:421-439.

Galloway, J. N., J. D. Aber, J. W. Erisman, S. P. Seitzinger, R. W. Howarth, E. B. Cowling, and B. J. Cosby. 2003. The nitrogen cascade. BioScience 53:341-356.

Gulis, V., and K. Suberkropp. 2003. Leaf litter decomposition and microbial activity in nutrient-enriched and unaltered reaches of a headwater stream. Freshwater Biology 48:123134.

Gulis, V., and K. Suberkropp. 2006. Fungi: biomass, production, and sporulation of aquatic hyphomycetes. Pages 311326 in F. R. Hauer and G. A. Lamberti, editors. Methods in stream ecology. Academic Press, Amsterdam, The Netherlands.

Hobbie, S. E. 2000. Interactions between litter lignin and soil nitrogen availability during leaf litter decomposition in a Hawaiian montane forest. Ecosystems 3:484-494.

Hobbie, S. E., and P. M. Vitousek. 2000. Nutrient limitation of decomposition in Hawaiian forests. Ecology 81:1867-1877.

Hunt, H. W., E. R. Ingham, D. C. Coleman, E. T. Elliott, and C. P. P. Reid. 1988. Nitrogen limitation of production and decomposition in prairie, mountain meadow, and pine forest. Ecology 69:1009-1016.

Hynes, H. B. N., and N. K. Kaushik. 1969. The relationship between dissolved nutrient salts and protein production in submerged autumnal leaves. Verhandlungen des Internationalen Verein Limnologie 17:95-103.

Magill, A. H., and J. D. Aber. 1998. Long-term effects of experimental nitrogen additions on foliar litter decay and humus formation in forest ecosystems. Plant and Soil 203: 301-311.

Manzoni, S., R. B. Jackson, J. A. Trofymow, and A. Porporato. 2008. The global stoichiometry of litter nitrogen mineralization. Science 321:684-686.

Manzoni, S., J. A. Trofymow, R. B. Jackson, and A. Porporato. 2010. Stoichiometric controls on carbon, nitrogen, and phosphorus dynamics in decomposing litter. Ecological Monographs 80:89-106.

McClaugherty, C. A., J. Pastor, and J. D. Aber. 1985. Forest litter decomposition in relation to soil nitrogen dynamics and litter quality. Ecology 66:266-275.

Melillo, J. M., J. D. Aber, and J. F. Muratore. 1982. Nitrogen and lignin control of hardwood leaf litter decomposition dynamics. Ecology 63:621-626.

Moore, T. R., J. A. Trofymow, C. E. Prescott, J. Fyles, and B. D. Titus. 2006. Patterns of carbon, nitrogen, and phosphorus dynamics in decomposing foliar litter in Canadian forests. Ecosystems 9:46-62.

Moorhead, D. L., and R. L. Sinsabaugh. 2006. A theoretical model of litter decay and microbial interaction. Ecological Monographs 76:151-174.

Mulholland, P. J., and W. R. Hill. 1997. Seasonal patterns in streamwater nutrient and dissolved organic carbon concentrations: separating catchment flow path and in-stream effects. Water Resources Research 33:1297-1306.

Newbold, J. D., J. W. Elwood, M. S. Schulze, R. W. Stark, and J. C. Barmeier. 1983. Continuous ammonium enrichment of a woodland stream: uptake kinetics, leaf decomposition, and nitrification. Freshwater Biology 13:193-204.

Parton, W., et al. 2007. Global-scale similarities in nitrogen release patterns during long-term decomposition. Science 315:361-364

Petersen, R. C., and K. W. Cummins. 1974. Leaf processing in a woodland stream. Freshwater Biology 4:343-368.

Peterson, B. J., et al. 2001. Control of nitrogen export from watersheds by headwater streams. Science 292:86-90.

Sanzone, D. M., J. L. Tank, J. L. Meyer, P. J. Mulholland, and S. E. G. Findlay. 2001. Microbial incorporation of nitrogen in stream detritus. Hydrobiologia 464:27-35.

Schlesinger, W. H., J. J. Cole, A. C. Finzi, and E. A. Holland. 2011. Introduction to coupled biogeochemical cycles. Frontiers in Ecology and the Environment 9:1-8.

Sinsabaugh, R. L., and S. Findlay. 1995. Microbial-production, enzyme-activity, and carbon turnover in surface sediments of the Hudson River estuary. Microbial Ecology 30:127-141.

Sinsabaugh, R. L., and J. J. F. Shah. 2011. Ecoenzymatic stoichiometry of recalcitrant organic matter decomposition: the growth rate hypothesis in reverse. Biogeochemistry 102: $31-43$.

Stark, J. M., and S. C. Hart. 1996. Diffusion technique for preparing salt solutions, Kjeldahl digests, and persulfate digests for nitrogen-15 analysis. Soil Science Society of America Journal 60:1846-1855.

Sterner, R. W., and J. J. Elser. 2002. Ecological stoichiometry: the biology of elements from molecules to the biosphere. First edition. Princeton University Press, Princeton, New Jersey, USA.

Suberkropp, K., and E. Chauvet. 1995. Regulation of leaf breakdown by fungi in streams - influences of water chemistry. Ecology 76:1433-1445.

Suberkropp, K., V. Gulis, A. D. Rosemond, and J. P. Benstead. 2010. Ecosystem and physiological scales of microbial responses to nutrients in a detritus-based stream: results of a 5-year continuous enrichment. Limnology and Oceanography $55: 149-160$.

Suberkropp, K., and M. J. Klug. 1976. Fungi and bacteria associated with leaves during processing in a woodland stream. Ecology 57:707-719. 
Suberkropp, K., and M. J. Klug. 1980. The maceration of deciduous leaf litter by aquatic hyphomycetes. Canadian Journal of Botany 58:1025-1031.

Triska, F. J., and J. R. Sedell. 1976. Decomposition of four species of leaf litter in response to nitrate manipulation. Ecology 57:783-792.

Vestgarden, L. S. 2001. Carbon and nitrogen turnover in the early stage of Scots pine (Pinus sylvestris L.) needle litter decomposition: effects of internal and external nitrogen. Soil Biology and Biochemistry 33:465-474.

Vitousek, P. M., H. A. Mooney, J. Lubchenco, and J. M. Melillo. 1997. Human domination of Earth's ecosystems. Science 277:494-499.

Vivanco, L., and A. T. Austin. 2011. Nitrogen addition stimulates forest litter decomposition and disrupts species interactions in Patagonia, Argentina. Global Change Biology 17:1963-1974.
Webster, J. R., E. F. Benfield, T. P. Ehrman, M. A. Schaeffer, J. L. Tank, J. J. Hutchens, and D. J. D'Angelo. 1999. What happens to allochthonous material that falls into streams? A synthesis of new and published information from Coweeta. Freshwater Biology 41:687-705.

Webster, J. R., J. D. Newbold, S. A. Thomas, H. M. Valett, and P. J. Mulholland. 2009. Nutrient uptake and mineralization during leaf decay in streams - a model simulation. International Review of Hydrobiology 94:372-390.

Weyers, H. S., and K. Suberkropp. 1996. Fungal and bacterial production during the breakdown of yellow poplar leaves in 2 streams. Journal of the North American Benthological Society 15:408-420.

Woodward, G., et al. 2012. Continental-scale effects of nutrient pollution on stream ecosystem functioning. Science 336: $1438-1440$. 